\title{
The reproductive biology of Pinguipes brasilianus Cuvier, 1829 (Osteichthyes: Pinguipedidae) in temperate rocky reefs of Argentina
}

\author{
Gabriela L. Villanueva-Gomila1, Gustavo J. Macchi' ${ }^{2,3}$, Martín D. Ehrlich ${ }^{2,4}$, Alejo J. \\ Irigoyen $^{1}$ and Leonardo A. Venerus ${ }^{1}$
}

\begin{abstract}
Pinguipes brasilianus is a conspicuous and abundant rocky-reef fish inhabiting the Northern Patagonian gulfs of Argentina, Southwest Atlantic. This study describes its reproductive biology in this region. We made macroscopic and histological descriptions of the testis and ovary development, analyzed the evolution of the gonadosomatic index (GSI) in both sexes throughout the year, and estimated fecundity and length at 50\% maturity for females. Pinguipes brasilianus is a multiple spawner with indeterminate annual fecundity and an extended reproductive season, encompassing austral spring and summer. Low GSI values in males (monthly means ranged between $0.11 \%$ and $0.75 \%$ ) and low relative fecundity in female fish (between 2 and 44 oocytes/g) are consistent with a need of close proximity between male and female during oocyte fertilization, sexual courtship and with spawning in pairs and/or within reef crevices. The estimated length at $50 \%$ maturity $( \pm \mathrm{SD})$ for females was $15.22 \pm 0.43 \mathrm{~cm}$ total length. Although P. brasilianus shares the main reproductive features of its congeneric species Pinguipes chilensis, male GSI and female length at 50\% maturity in P. brasilianus were markedly lower than those reported for $P$. chilensis, while relative and batch fecundity were greater in fish of the same size.
\end{abstract}

Pinguipes brasilianus es una especie abundante en los arrecifes rocosos de los golfos norpatagónicos de Argentina, en el Atlántico Sudoccidental. En este trabajo estudiamos su biología reproductiva, incluyendo la descripción macroscópica e histológica del desarrollo de testículos y ovarios, el análisis de la evolución del índice gonadosomático (IGS) para ambos sexos a lo largo del ciclo anual, y la estimación de la fecundidad y la talla de primera madurez para las hembras. Pinguipes brasilianus es un desovante múltiple con fecundidad indeterminada y una estación reproductiva extensa que abarca la primavera y el verano australes. Los bajos valores de IGS en machos (el promedio mensual varió entre $0,11 \%$ y $0,75 \%$ ), y la baja fecundidad relativa en las hembras (entre 2 y 4 oocitos/g) son consistentes con un sistema de apareamiento que involucra una estrecha proximidad entre machos y hembras durante la fertilización de los oocitos, cortejo y desove en parejas y/o en áreas confinadas (ej.: refugios). La talla de primera madurez ( $\pm \mathrm{DE}$ ) estimada para las hembras fue de $15,22 \pm$ $0,43 \mathrm{~cm}$ de largo total. Aunque P. brasilianus comparte los principales rasgos reproductivos con Pinguipes chilensis, tanto los valores promedio de IGS en machos como la talla de primera madurez en hembras fueron menores que los reportados para $P$. chilensis, mientras que la fecundidad (parcial y relativa) fue mayor.

Keywords: Batch fecundity, Gonadosomatic index, Length at 50\% maturity, Rocky-reef fishes, Southwest Atlantic.

\section{Introduction}

Pinguipedidae (Perciformes), mostly represented by tropical and warm-temperate species, is composed by demersal marine fishes distributed along the Atlantic and Pacific coasts of South America, the Atlantic coast of
Africa, and the Indo-Pacific (to New Zealand and Hawaii) (Nelson, 2006). South American waters are inhabited by three endemic genera: Pinguipes Cuvier, 1829, Prolatilus Gill, 1865, and Pseudopercis Miranda Ribeiro 1903, and by a single species of Parapercis (Bleeker, 1863) (Nelson, 2006). The genus Pinguipes is represented solely by

${ }^{1}$ Centro para el Estudio de Sistemas Marinos, Centro Nacional Patagónico, Consejo Nacional de Investigaciones Científicas y Técnicas (CESIMAR- CENPAT-CONICET), Boulevard Brown 2915 (U9120ACD), Puerto Madryn, Chubut, Argentina. (GLVG) gomila@cenpatconicet.gob.ar (corresponding author), (AJI) alejo@cenpat-conicet.gob.ar, (LAV) leo@cenpat-conicet.gob.ar

${ }^{2}$ Instituto Nacional de Investigación y Desarrollo Pesquero (INIDEP) PO Box 175, (B7602HSA), Mar del Plata, Buenos Aires, Argentina. (GJM) gmacchi@inidep.edu.ar, (MDE)mehrlich@inidep.edu.ar

${ }^{3}$ Consejo Nacional de Investigaciones Científicas y Técnicas (CONICET).

${ }^{4}$ Departamento de Ecología, Genética y Evolución, Instituto IEGEBA (CONICET-UBA) Facultad de Ciencias Exactas y Naturales, Universidad de Buenos Aires, Intendente Güiraldes 2160, Ciudad Universitaria, (C1428EGA), Ciudad Autónoma de Buenos Aires, Argentina. 
two species: the Chilean sandperch Pinguipes chilensis Valenciennes, 1833, distributed from Tumbes, Peru $\left(3^{\circ} 34^{\prime} \mathrm{S}\right)$, to Magallanes, Chile $\left(52^{\circ} 00^{\prime} \mathrm{S}\right)$ (Rosa \& Rosa, 1997; González Kother, 2001), and the Brazilian sandperch Pinguipes brasilianus Cuvier, 1829, distributed from Rio de Janeiro, Brazil $\left(22^{\circ} 30^{\prime} \mathrm{S}\right)$, to San Jorge gulf, Argentina (4550'S) (Galván et al., 2009a; but see Orsi Relini, 2002 for a report of this species in Mediterranean waters).

Information about the reproductive biology of pinguipedid fishes is available for the genera Parapercis, Pseudopercis and Pinguipes: the reproductive mode (Stroud, 1982; Macchi et al., 1995), frequency of spawning (Stroud, 1982; Beer et al., 2013), duration of the spawning season, and seasonal evolution of the gonadosomatic index (GSI) (Macchi et al., 1995; González, 1998; González \& Oyarzún, 2002) were studied for a few species. The congeneric $P$. chilensis is a dioicus species with external fecundity and an extended spawning season (González Kother, 2001). As it is common within the family, $P$. chilensis have batch fecundity (Stroud, 1982; Macchi et al., 1995; González \& Oyarzún, 2002; Beer et al., 2013), but its male GSI values (mean range: 0.96-3.37\%, see González Kother, 2001) are higher than the observed for other pinguipedids (in general <1\%; e.g., González, 1998; Carbines, 2004).

Although P. brasilianus is one of the most conspicuous (maximum length and weight round $45 \mathrm{~cm}$ and $1.25 \mathrm{~kg}$, respectively) and abundant fishes that compound the low-diversity rocky reef fish assemblage of the Northern Patagonian gulfs of Argentina (Galván et al., 2009a; Irigoyen et al., 2013), it has received little scientific attention. This species, as other common reef fishes like Pseudopercis semifasciata (Cuvier, 1829), Acanthistius patachonicus (Jenyns, 1840) and Sebastes oculatus Valenciennes, 1833, constitutes a major attraction for recreational divers and spear fishers that operate near Puerto Madryn and Puerto Pirámide, the most important tourist centres within Peninsula Valdés (Sanabra, 2002; Venerus, 2006), and along the Northern Patagonian coast of Argentina. Previous studies on P. brasilianus focused on its biomass as a potential fishery resource (Otero et al., 1982), morphological and osteological features (Herrera \& Cousseau, 1996; Rosa \& Rosa, 1997), parasitic fauna (Timi et al., 2010), diet (Galván et al., 2009b), and spatiotemporal dynamics (Galván, 2008; Irigoyen et al., 2013).

With the aim of gaining insight into the reproductive strategy and the population dynamics of one of the conspicuous, most abundant species from Northern Patagonia rocky reefs, we describe for the first time the reproductive biology of $P$. brasilianus off the coast of Argentina. In addition, we provide macroscopic and histological descriptions of the gonad development, as well as fecundity estimates. The results may be relevant to help identifying appropriate strategies for managing this species in temperate rocky reefs from Northern Patagonia.

\section{Material and Methods}

Sampling. Specimens were hand-lined or spear-fished within the Northern Patagonian gulfs San Matías, San José and Nuevo $\left(41^{\circ} 23^{\prime} \mathrm{S}\right.$ to $\left.42^{\circ} 57^{\prime} \mathrm{S}\right)$, and trawled off Rawson city $\left(43^{\circ} 15^{\prime} \mathrm{S}\right.$ to $\left.43^{\circ} 45^{\prime} \mathrm{S}\right)$. Additional samples were obtained from the recreational angling and spear fisheries that take place in those gulfs. Although the samples were collected between August 2009 and July 2013, they were pooled by month of capture, irrespective of location, date and year, for the different analyzes, because of the low number of specimens collected in each sampling date. Between 14 and 41 males and between 5 and 25 females were available per month, which would cover a whole annual cycle. A total of 165 females (size range: $11.5-42.5 \mathrm{~cm}$ total length, $\mathrm{TL}$ ) and 236 males (size range: $12.5-44.5 \mathrm{~cm} \mathrm{TL}$ ) were included in this study (Table 1).

Table 1. Number of Pinguipes brasilianus used for each analysis, categorized by sex and month. The size range (TL, in $\mathrm{cm}$ ) is showed in parenthesis. Note that most fish sampled in summer (January to March) came from the monitoring of the recreational fishery, and hence it was only possible to keep the gonads but not the whole fish to estimate GSI. W/d: without data.

\begin{tabular}{|c|c|c|c|c|c|c|c|}
\hline \multirow{2}{*}{ Month } & \multirow{2}{*}{$\begin{array}{c}\text { Fecundity } \\
\text { Females }\end{array}$} & \multicolumn{2}{|c|}{ GSI } & \multicolumn{2}{|c|}{ Histological analysis and $\mathrm{L}_{50}$ estimation (females only) } & \multicolumn{2}{|c|}{ Total fish sampled } \\
\hline & & Females & Males & Females & Males & Females & Males \\
\hline Jan & $4(34.0-42.0)$ & $4(28.5-40.0)$ & $9(14.0-41.0)$ & $19(16.0-42.0)$ & $22(14.0-43.0)$ & 21 & 24 \\
\hline Feb & $\mathrm{w} / \mathrm{d}$ & $15(15.5-29.0)$ & $21(12.5-35.0)$ & $22(15.5-40.5)$ & $24(12.5-43.0)$ & 25 & 36 \\
\hline Mar & $1(27.0)$ & $\mathrm{w} / \mathrm{d}$ & $13(23.0-41.0)$ & $16(14.5-42.5)$ & $21(25.0-44.5)$ & 17 & 23 \\
\hline Apr & $\mathrm{w} / \mathrm{d}$ & $5(27.5-34.5)$ & $10(24.0-36.0)$ & $5(27.5-34.5)$ & $10(24.0-35.5)$ & 5 & 14 \\
\hline Jul & $\mathrm{w} / \mathrm{d}$ & $19(22.0-41.0)$ & $18(24.0-41.0)$ & $18(22.0-41.0)$ & $18(24.0-41.0)$ & 19 & 19 \\
\hline Aug & $\mathrm{w} / \mathrm{d}$ & $13(28.5-42.0)$ & $16(24.0-43.5)$ & $13(28.5-42.0)$ & $13(24.0-43.5)$ & 13 & 17 \\
\hline Sep & $\mathrm{w} / \mathrm{d}$ & $14(25.0-37.5)$ & $39(23.0-42.0)$ & $13(20.5-37.5)$ & $32(23.0-42.0)$ & 18 & 41 \\
\hline Oct & $2(33.5-36.0)$ & $15(17.5-37.5)$ & $17(18.0-42.0)$ & $15(17.5-37.5)$ & $16(18.0-42.0)$ & 17 & 21 \\
\hline Nov & $3(24.0-33.5)$ & $19(14.5-37.5)$ & $17(23.5-42.0)$ & $19(14.0-36.0)$ & $16(23.5-39.5)$ & 21 & 19 \\
\hline Dec & $\mathrm{w} / \mathrm{d}$ & $7(17.5-38.0)$ & $20(15.0-40.0)$ & $7(17.5-36.0)$ & $16(15.0-40.0)$ & 9 & 21 \\
\hline Total & 10 & 111 & 180 & 147 & 188 & 165 & 236 \\
\hline
\end{tabular}


Total fish length, measured to the lowest mid-centimeter, and total body mass (TW) $\pm 1.0 \mathrm{~g}$ were recorded for each fish. Specimens were dissected for sex determination, gonads were weighed $(\mathrm{GW}) \pm 0.1 \mathrm{mg}$ and fixed in formalin $10 \%$. A transversal portion of $\sim 1$-g sample was removed from each gonad, and manually dehydrated in ethanol for $3 \mathrm{~h}$, cleared in xylol for other $3 \mathrm{~h}$ and embedded in paraffin during $24 \mathrm{~h}$. Sections were cut at $5-\mu \mathrm{m}$ thickness with a microtome (Yamato PR-50) and stained with Harris's hematoxylin followed by eosin counterstain (García del Moral Martín, 1993).

Reproductive cycle. The reproductive cycle was inferred from the proportion of gonads in different maturity stages and from the evolution of the gonadosomatic index GSI $=100 \mathrm{GW} /(\mathrm{TW}-\mathrm{GW})$ (Cailliet et al., 1986) throughout the year. Gonad maturity classification, applied to 147 females (14.0-42.5 cm TL) and 188 males (12.5-44.5 $\mathrm{cm}$ TL) (Table 1), was based on a modified microscopic classification scheme proposed by Brown-Peterson et al. (2011). Five microscopic stages were defined for each sex based on the most advanced gamete stage present and by some distinctive features of the gonads of $P$. brasilianus (Table 2). We estimated 95\% confidence intervals (CI) for the monthly fraction of spawning-capable fish following the method by Clopper \& Pearson (1934) for binomial proportions.

GSI values were calculated only for mature specimens: fish $>21.0 \mathrm{~cm}$ TL (assumed to be mature, see Results) and those $<21.0 \mathrm{~cm}$ TL categorized as such by the histological analysis, which totalized 111 females $(14.5-42.0 \mathrm{~cm} \mathrm{TL})$ and 180 males (12.5-43.5 cm TL) (Table 1). Seasonal trends in GSI were evaluated separately for each sex. As the inspection of the raw data suggested heterogeneous variance, we used generalized least squares models for allowing heterogeneity (Zuur et al., 2009). Total fish length and month were tested as potential explanatory variables.

In addition, the relationship between water temperature and photoperiod vs. GSI was assessed by fitting two generalized lineal models, one for each variable (McCullagh \& Nelder, 1989; Zuur et al., 2009). Plots of standardized residuals against fitted values were used to select the most appropriate error structure and link functions (Gaussian and gamma errors were tested). Monthly mean sea surface temperature (SST) data for the gulfs San Matías, San José and Nuevo, and for waters off Rawson city was estimated from level 3 data collected by MODIS-Aqua from 2003 through 2013 and downloaded from NASA's Giovanni web site (http://daac.gsfc. nasa.gov/giovanni/). The time (in hours) between sunrise and sunset was used as a proxy for photoperiod. Monthly mean values were estimated from daily data for Punta Delgada, Península Valdés $\left(42^{\circ} 46^{\prime} \mathrm{S}\right.$ $63^{\circ} 38^{\prime} \mathrm{W}$ ) (downloaded from http://www.hidro.gob.ar/ observatorio/Sol.asp).

Maturity. Female length at $50 \%$ maturity $\left(\mathrm{L}_{50}\right)$ was estimated by fitting a series of generalized linear models with quasibinomial error structure (that allows to deal with overdispersion) and a logit link function to the proportion of mature females ( $n=145,14.0-42.5 \mathrm{~cm}$ TL, Table 1), grouped into 2-, 3-, 4- and 5-cm length intervals (e.g., International Council for the Exploration of the Sea (ICES), 2008). Then, the fit with less uncertainty around the $\mathrm{L}_{50}$ estimate was chosen as the best model. Proportions of mature females were weighted according to the sample size.

Fecundity and spawning pattern. Ten mature female fish, not recently spawned (24.0-42.0 cm TL) were used for fecundity estimation (Table 1). Those characteristics were inferred from the presence of hydrated oocytes and the absence of new postovulatory follicles (POFs) (Murua \& Saborido-Rey, 2003). Between one and three $\sim 1$-g samples were cut from the ten ovaries, belonging to different fish $(n=21)$. To avoid any biases originated from potential differences in oocyte development along the length of the ovaries, we compared the numbers of hydrated oocytes per $\mathrm{g}$ of gonad, transversally cut from the anterior, middle and posterior areas of five randomly selected ovaries (Hunter et al., 1985), by running a non-parametric Quade test (Quade, 1979). We chose a non-parametric test in this case because the low number of samples did not allow us to test normality properly.

Table 2. Gonad maturity classification in Pinguipes brasilianus based on a modified microscopic classification scheme proposed by Brown-Peterson et al. (2011). CAO: Cortical alveoli oocyte; GE: germinal epithelium; HO: hydrated oocyte; PGO: primary growth oocyte; POF: postovulatory follicle; Sc1: primary spermatocyte; Sc2: secondary spermatocyte; Sg: spermatogonia; St: spermatid; Sz: spermatozoa; VtgO: vitellogenic oocyte.

\begin{tabular}{lll}
\hline \multirow{2}{*}{ Stages } & \multicolumn{1}{c}{ Ovary } & \multicolumn{1}{c}{ Histological features } \\
\cline { 2 - 3 } Immature & Small ovaries with a thin tunic. PGO present. & Only Sg are present; no lumen in lobules. \\
Developing & CAO and VtgO only. & $\begin{array}{l}\text { Sc1, Sc2, St, and Sz can be present in cysts. Continuous GE. } \\
\text { Early developing subphase: Sg and Sc1 only. }\end{array}$ \\
Spawning capable & POF, HO. & Abundant Sz in lumen of lobules and in sperm ducts. \\
Regressing & Abundant atresia of VtgO. & Residual Sz present in lumen of lobules and in sperm ducts. Sc2, St, Sz. \\
Regenerating & PGO, thick ovarian tunica. & Proliferation of Sg and continuous GE throughout the testes. Small amounts of residual Sz. \\
\hline
\end{tabular}


As the selection of the method for estimating fecundity depends on the pattern of oocyte development (i.e., determinate or indeterminate fecundity), we analyzed the oocyte size-frequency distribution in a subset of three females, prior to deciding which approach should be used for P. brasilianus (Hunter et al., 1985). Oocytes $>100 \mu \mathrm{m}$ were brushed apart from the ovary samples and were measured macroscopically on a random orientation basis from digital photographs (5.5 Mpx) by using the free software ImageJ. When oocytes were not perfectly spherical in shape, we measured the largest axis. Then we grouped size data in 100 $\mu \mathrm{m}$ classes and inferred the spawning pattern from visual inspection of the resulting distributions (West, 1990). As the oocyte size-frequency distributions were multimodal (see results), we estimated batch fecundity following the hydrated oocyte method described in Hunter et al. (1985), and relative fecundity, for each female:

$$
B F=\frac{\sum_{i=1}^{n}\left(\frac{H_{i}}{W_{i}}\right)}{n} G W
$$

where: $B F=$ batch fecundity, $H_{i}=$ number of hydrated oocytes in each ovary sample $i, W i=$ weight of each ovary sample $i, n=$ number of ovary samples, and $G W=$ weight of both ovaries; and

$$
R F=\frac{B F}{T W_{W O}} G W
$$

where: $R F=$ relative fecundity, and $T W_{W O}=$ total weight excluding the ovaries.

Finally, we described the relationship between batch and relative fecundity versus fish length by fitting both power and exponential functions of the forms:

$$
\begin{gathered}
F_{P}=a T L^{b} \text { (3), and } \\
F_{E}=c \exp (T L d)
\end{gathered}
$$

where the sub indexes $P$ and $E$ represent the type of function (power and exponential, respectively), and $a, b, c$ and $d$ are model parameters. We used non-linear least squares for fitting the models. Data were weighted according to the number of ovary samples used for estimating each fecundity value.

Model fitting. All models were fitted by using the packages 'nlme' (Pinheiro et al., 2014), 'nls2' (Grothendieck, 2007) and 'stats' included in the R software (R Development Core Team, 2014). Generalized least squares and generalized linear models were fitted by using the gls and glm functions, respectively. The power and exponential functions were fitted with the nls2 function. The Quade test was run with the quade.test function of the 'stats' $\mathrm{R}$ package. The corrected Akaike Information Criteria (AICc) was used for model selection (Burnham \& Anderson, 2004), with the exception of the quasibinomial model for which it is not defined (see Zuur et al., 2009). To analyze the evolution of GSI, P-values were adjusted for multiple comparisons among model coefficients by the sequential rejective Bonferroni test (Holm, 1979) with the p.adjust function (R Development Core Team, 2014).

Abbreviations list. AIC: Akaike Information Criteria; CI: confidence interval; CAO: cortical alveoli oocytes; GE: germinal epithelium; GSI: gonadosomatic index; HO: hydrated oocytes; $\mathrm{L}_{50}$ : length at $50 \%$ maturity; POF: postovulatory follicles; PGO: primary growth oocytes; Sc1: primary spermatocytes; SST: Sea surface temperature; Sc2: secondary spermatocytes; St: spermatid; Sg: spermatogonia; Sz: spermatozoa; TL: total length; VtgO: vitellogenic oocytes.

\section{Results}

Gonads development. Pinguipes brasilianus is a dioicus species. Its gonads, located in the antero-dorsal region of the peritoneal cavity, are elongated and symmetrical. The testes are white, triangular in section and lobular in structure. During the spent period their color turns into grey. The ovaries are circular in section and their color changes from orange to reddish during the spent period.

During the immature phase in female fish, primary growth oocytes (PGO) were observed in the ovaries (Table 2, Fig. 1a). The appearance of cortical alveoli oocytes (CAO) indicated that fish had already reached sexual maturity. Gonads having CAO as the most advanced oocyte type are considered to be in the developing phase, which also comprehend those ovaries containing vitellogenic oocytes (VtgO) (Fig. 1b), or with signs of prior spawning. The spawning capable phase, defined by the presence of oocytes in hydration, ovulation or with postovulatory follicles (POFs) (Fig. 1c), indicates that release of gametes may be imminent or that spawning occurred recently. The cycle continues with the regressing phase, characterized by the presence of abundant atresias (Fig. 1d). Regenerating is the last phase of the developmental cycle; it is represented by the presence of PGO and a thick ovarian tunica (Fig. 1e). Females are reproductively inactive at this stage.

Immature males were not caught. Early developing males were characterized by the presence of spermatogonia $(\mathrm{Sg})$ and primary spermatocytes (Sc1) (Table 2, Fig. 2a). Males having $\mathrm{Sc} 1$, secondary spermatocytes $(\mathrm{Sc} 2)$, spermatid (St) and spermatozoa $(\mathrm{Sz})$ within the spermatocysts in their testis remain in the developing phase (Fig. 2b). Sz were the most abundant germ cells in the spawning capable phase (Fig. 2c). The cycle continues with the regressing phase, characterized by the absence of $\mathrm{Sz}$ in the sperm ducts and in the lumen of the lobules, cessation of spermatogenesis, and a decreased number of spermatocysts (Fig. 2d). During the regenerating phase, fish are sexually mature but reproductively inactive. Gametes are undergoing active gonadotropin-independent mitotic proliferation in preparation for the next reproductive cycle (Fig. 2e). 


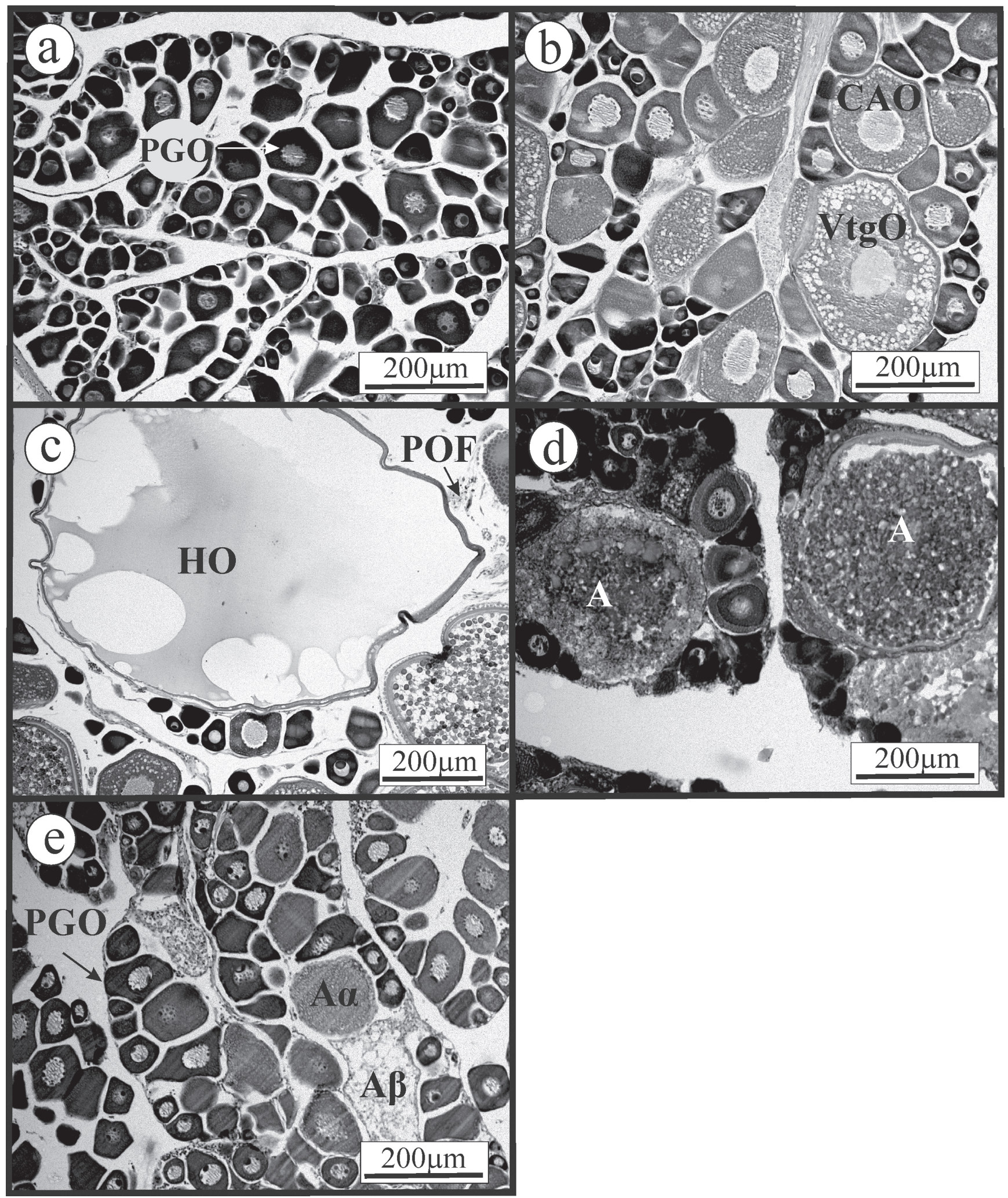

Fig. 1. Ovaries of Pinguipes brasilianus in different maturation stages. a) immature, b) developing, c) spawning capable, d) regressing, e) regenerating. A: atresia ( $\alpha$ and $\beta$ ); CAO: Cortical alveoli oocyte; HO: hydrated oocyte; PGO: primary growth oocyte; POF: postovulatory follicle; $\mathrm{VtgO}$ : vitellogenic oocyte. 


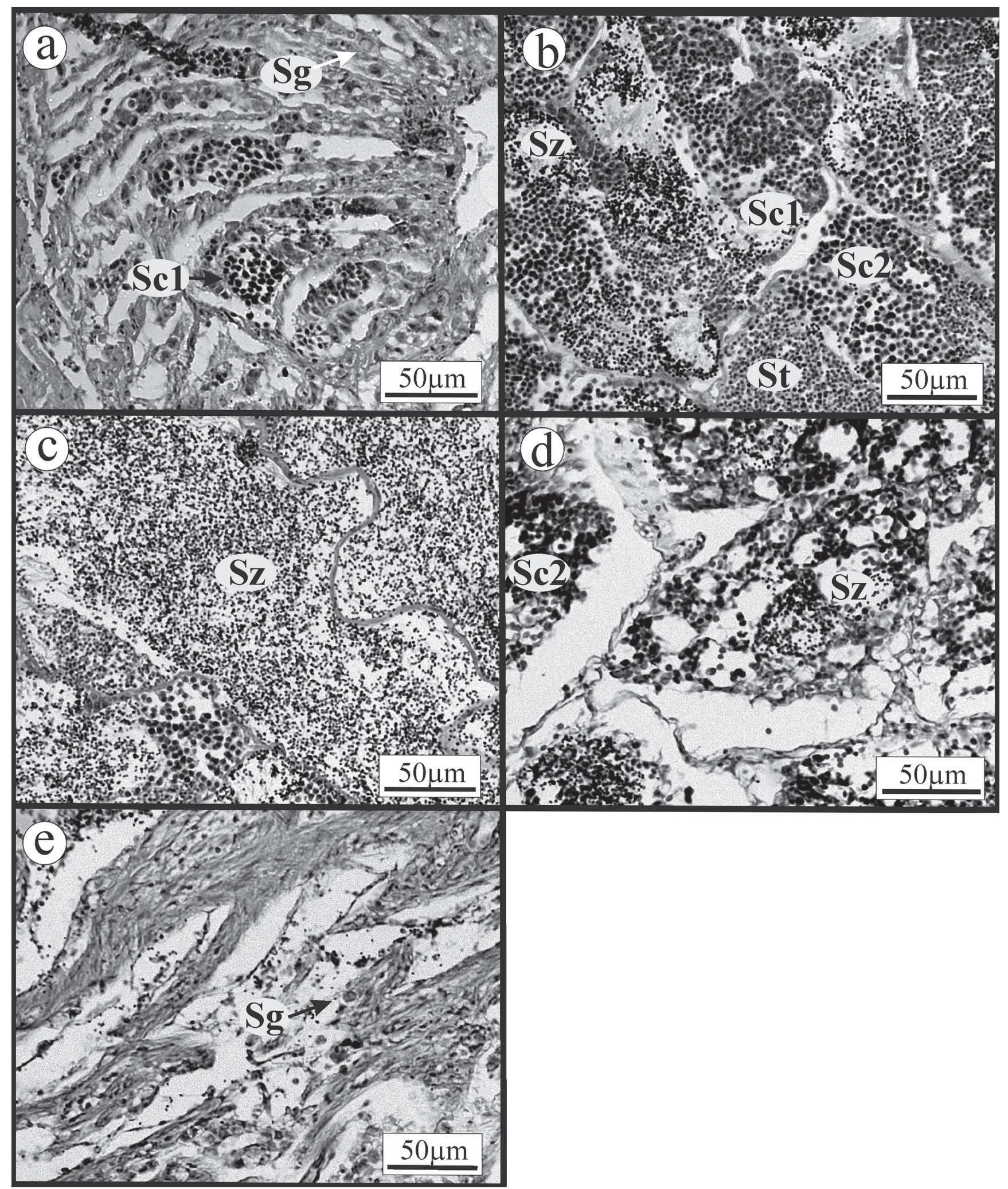

Fig. 2. Testicles of Pinguipes brasilianus in different maturation stages. a) early developing, b) developing, c) spawning capable, d) regressing, e) regenerating. Sc1: primary spermatocyte; Sc2: secondary spermatocyte; Sg: spermatogonia; St: spermatid, Sz: spermatozoa. 
Reproductive cycle and maturity. Both the histological analysis and the evolution of the GSI values pointed to an extended reproductive season for $P$. brasilianus in Northern Patagonia, encompassing spring and summer months. Virtually all sampled females were found in the spawning capable stage between November (mean: $89 \%$; CI 95\%: [65\%; 99\%]) and February (mean: $86 \%$; CI 95\%: [64\%; 97\%]), coincidently with the highest proportions of hydrated oocytes in the ovaries. However, some fish were already sampled in this stage in August (mean: 46\%; CI 95\%: [19\%; 75\%]), September (mean: 50\%; CI 95\%: [21\%; 79\%]) and October (mean: 33\%; CI 95\%: [12\%; 62\%]) (Figs. 3a and S1, available as Supplementary Material). The end of the spawning season was marked by the presence of females in regressing and regenerating stages, mainly during March (86\%) and April (80\%), respectively (Fig. 3). No females were found ripe in July.

The reproductive cycle was less marked in males, as mature fish in developing and spawning capable stages predominated throughout the year, particularly between August and March (Figs. 3 and S1, available as Supplementary Material). Regressing and regenerating phases (6-29\%) were only found between March and August.

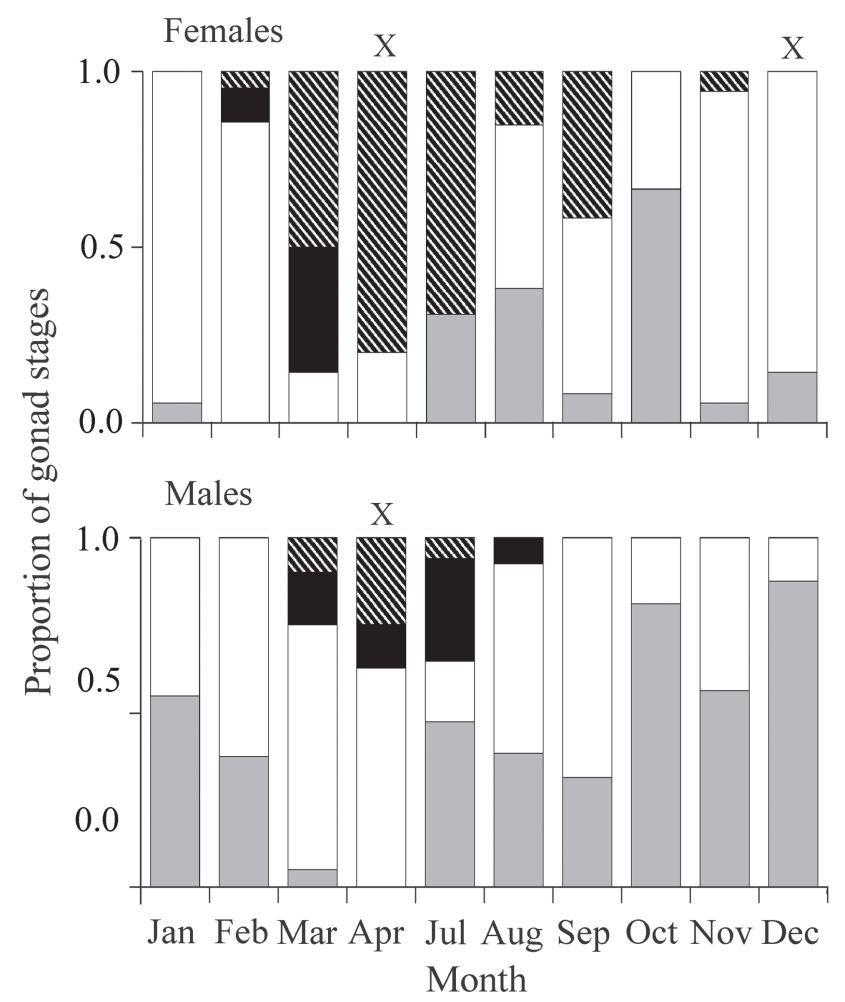

$\mathbb{N}$ Regenerating $\square$ Regressing $\square$ Spawning capable $\square$ Developing

Fig. 3. Monthly evolution of the proportion of gonad stages (excluding immature fish) for females $(n=147)$ and males $(n=188)$ Pinguipes brasilianus. The X symbol over some bars indicates those cases in which ten or less gonads were classified.
Monthly mean GSI values for P. brasilianus ranged between $0.73 \%$ and $5.51 \%$ in females, and between $0.11 \%$ and $0.75 \%$ in males (Fig. 4). The evolution of this index matched the pattern inferred from gonadal maturation. The selected GSI models for each sex included the explanatory variables TL and month (Table 3). Heterogeneity was incorporated into the models by allowing each month having a different variance. Irrespective of sex, the gonadosomatic index increased smoothly with fish length (females: slope $=0.052$, Student- $\mathrm{t}=4.50, P<<0.001$; males: slope $=0.006$, Student- $\mathrm{t}=3.34 ; P=0.001)$. Although results from multiple contrasts between months were rather messy (Fig. 4), both sexes had larger mean GSI values during spring and summer (approximately between October and February). While males maintained low mean GSI values between March and September, females had intermediate values from August through October, and a maximum in January (mean \pm standard deviation $[\mathrm{SD}]=5.51 \% \pm 2.48 \%$ ).

Females

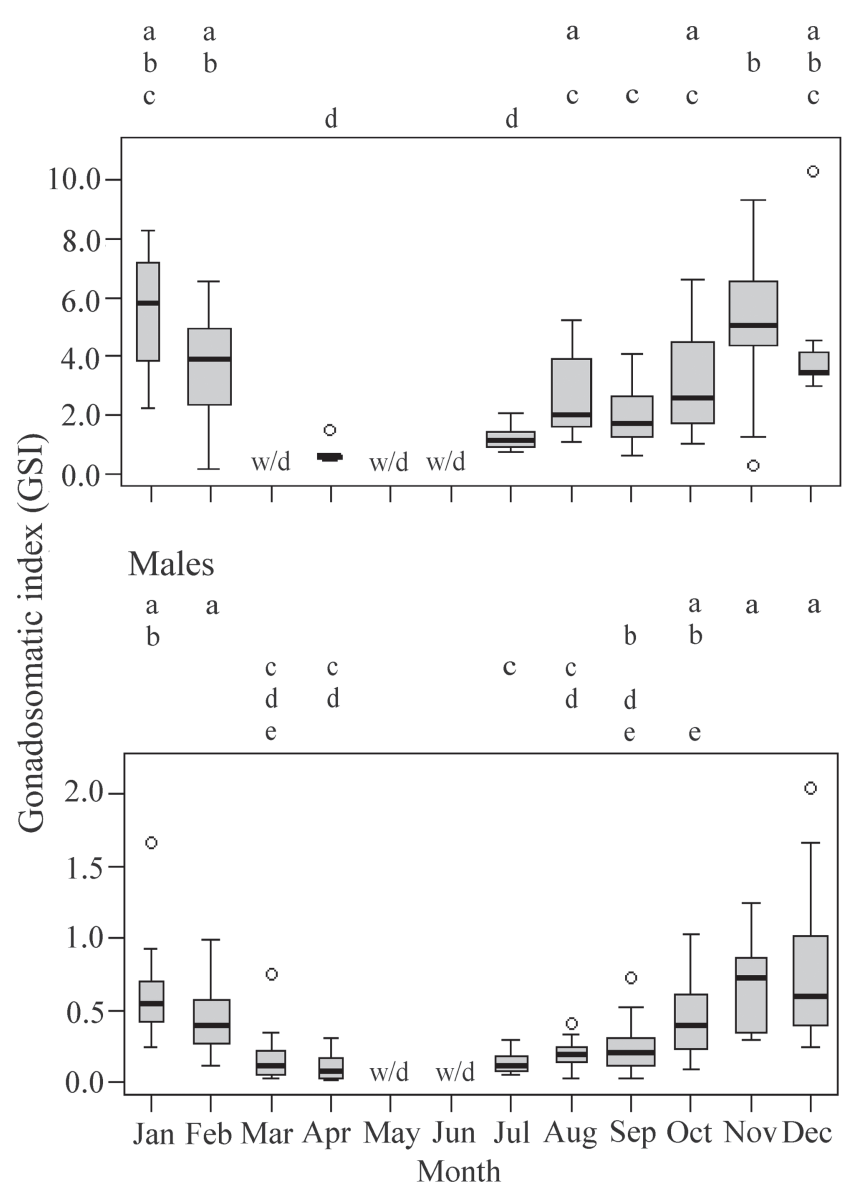

Fig. 4. Boxplots showing monthly distributions of the gonadosomatic index for females and males Pinguipes brasilianus. The lower case letters identify homogeneous groups based on the sequential rejected Bonferroni contrasts among levels for the factor 'month' (letter displays were obtained with the package multcompView, $\mathrm{R}$ software [R Development Core Team, 2014]). W/d: without data. 
Table 3. Generalized least squares model coefficients, standard errors (SE) and 95\% confidence intervals (CI) for the gonadosomatic index in females (a) and males (b) Pinguipes brasilianus. The asterisks indicate significant differences $(P<0.05)$ between each level and the reference level for each term included in the intercept estimate.

\begin{tabular}{lcccc}
\hline \multicolumn{1}{c}{ Level } & & Coefficient & SE & CI $(95 \%)$ \\
\hline a) Females & & & & \\
\hline Intercept & & $3.655 *$ & 1.220 & $1.135 ; 5.917$ \\
\hline & Feb & -1.245 & 1.269 & $-3.732 ; 1.242$ \\
& Apr & $-4.506 *$ & 1.160 & $-6.780 ;-2.232$ \\
& Jul & $-4.169 *$ & 1.151 & $-6.425 ;-1.913$ \\
Month & Aug & $-2.742 *$ & 1.216 & $-5.125 ;-0.359$ \\
& Sep & $-3.265 *$ & 1.176 & $-5.570 ;-0.960$ \\
& Oct & -2.239 & 1.236 & $-4.670 ; 0.191$ \\
& Nov & -0.053 & 1.269 & $-2.540 ; 2.434$ \\
Length (TL) & Dec & -0.689 & 1.586 & $-3.805 ; 2.427$ \\
\hline b ) Males & & $0.052 *$ & 0.012 & $0.028 ; 0.076$ \\
\hline Intercept & & & & \\
\hline & Feb & -0.198 & 0.153 & $-0.495 ; 0.101$ \\
& Mar & $-0.479 *$ & 0.151 & $-0.775 ;-0.183$ \\
& Apr & $-0.551 *$ & 0.147 & $-0.839 ;-0.263$ \\
& Jul & $-0.540 *$ & 0.145 & $-0.822 ;-0.254$ \\
& Aug & $-0.493 *$ & 0.146 & $-0.776 ;-0.204$ \\
& Sep & $-0.447 *$ & 0.146 & $-0.730 ;-0.162$ \\
& Oct & $-0.207 *$ & 0.156 & $0.258 ; 0.468$ \\
& Nov & 0.005 & 0.162 & $-0.312 ; 0.324$ \\
& Dec & 0.101 & 0.182 & $-0.256 ; 0.458$ \\
& & $0.006 *$ & 0.002 & $0.002 ; 0.010$ \\
\hline & & &
\end{tabular}

Gamma models with log link were selected for evaluating the relationship between GSI vs. photoperiod and SST, respectively. In both sexes, GSI increased with photoperiod (females: slope $=0.208$, Student- $\mathrm{t}=8.04, P<0.001$; males: slope $=0.287$, Student- $\mathrm{t}=11.70 ; P<0.001$ ) and SST (females: slope $=0.084$, Student $\mathrm{t}=3.54, P<<0.001$; males: slope $=$ 0.09 , Student- $\mathrm{t}=4.45 ; P<<0.001)$ (Figs. S2-S3, available as Supplementary Material). The models reduced significantly the residual deviance and explained $32.6 \%$ and $39.4 \%$ (photoperiod), and $8.0 \%$ and $7.8 \%$ (SST) of the variability in the data for females and males, respectively. Between November and February, daytime for the study area ranged between 14.5 and $15.0 \mathrm{~h}$ and SST, between $13.5^{\circ} \mathrm{C}$ and $19.0^{\circ} \mathrm{C}$. From August through October, when roughly half of the females were found spawning capable, daytime ranged between 10 and $13 \mathrm{~h}$, and SST, between $10.5^{\circ}$ and $12.0^{\circ} \mathrm{C}$.

Greatest accuracy for female $\mathrm{L}_{50}$ was obtained by grouping fish length by $3-\mathrm{cm}$ TL classes. Best female maturity model explained $97 \%$ of the variability in the proportion of mature fish. The estimated $\mathrm{L}_{50}$ was $15.22 \pm$ $0.43 \mathrm{~cm} \mathrm{TL}(\mathrm{F}=230.42, P<<0.001)$ (Fig. 5). The smallest mature female sampled was $14.0 \mathrm{~cm} \mathrm{TL}$, and by $20.5 \mathrm{~cm}$ TL all fish sampled were already mature. Although male
$\mathrm{L}_{50}$ could not be estimated because lack of data, the smallest mature male was $12.5 \mathrm{~cm}$ TL and the largest immature fish was $33 \mathrm{~cm}$ TL.

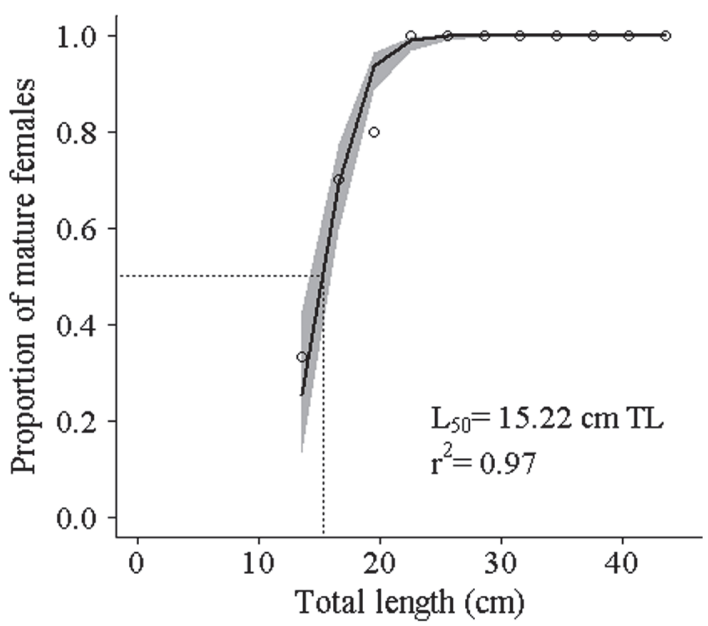

Fig. 5. Proportion of mature females per $3-\mathrm{cm}$ length classes of Pinguipes brasilianus. Shaded areas represent $95 \%$ confidence regions and dotted lines indicate length at $50 \%$ maturity $\left(\mathrm{L}_{50}\right)$.

Spawning frequency and batch fecundity. The coexistence of batches of oocytes in different vitellogenic stages was evident from the multimodal frequency distributions of oocyte diameters for gravid females (Fig. 6). Due to the compatibility between this and an indeterminate annual fecundity pattern, we estimated batch fecundity for $P$. brasilianus. Hydrated oocytes (i.e., $>700 \mu \mathrm{m})$ were uniformly distributed across the ovary (Quade $\mathrm{F}=3.28 ; P=0.091$ ). Most of the gravid females sampled had simultaneously hydrated oocytes and POFs.

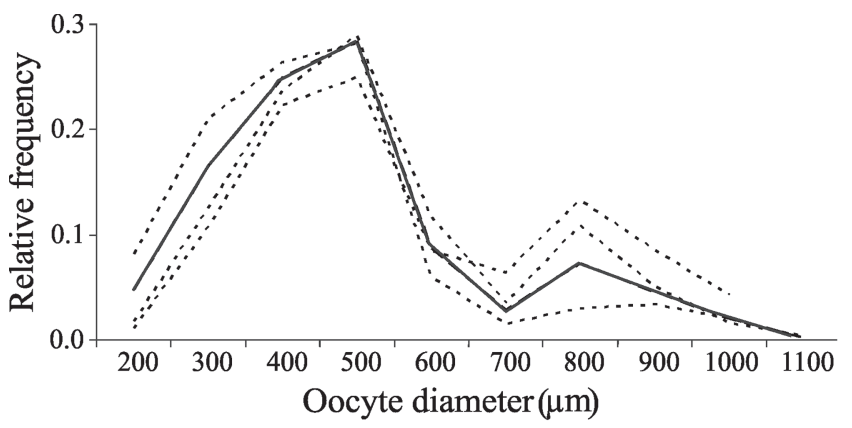

Fig. 6. Size frequency distributions of oocyte diameter grouped per $100 \mu \mathrm{m}$ in actively spawning female Pinguipes brasilianus. Dotted lines show the relative frequencies for three different fish, and the solid line, the distribution obtained by pooling all data.

Mean batch fecundity \pm SD was $16,328 \pm 14,826$ hydrated oocytes, and ranged between 342 (in 24.0 -cm-TL female) and 47,949 (in a 42.0-cm-TL female). Batch fecundity increased nonlinearly with TL. Both the power and exponential models fitted well to the data, and the AIC did not allow to chose the 
best model between them (AIC values $=154.8$ and 154.7, for the power and exponential functions, respectively). Model parameters were $a_{B F}=1.09 \mathrm{e}-07 \pm 4.33 \mathrm{e}-07$ and $b_{B F}=7.16 \pm$ 1.07 for the power function, and $c_{B F}=17.38 \pm 18.66$ and $d_{B F}$ $=0.19 \pm 0.03$ for the exponential function (Fig. 7a). Mean relative fecundity \pm SD for fish between $24.0 \mathrm{~cm}$ and 40.0 $\mathrm{cm}$ TL was $23.24 \pm 17.42$ oocytes/g and ranged between 2.04 and 43.90 oocytes/g, respectively. Mean relative fecundity also increased with size (Fig. 7b), and again, the AIC did not allow to chose the best model between the power and the exponential functions (AIC values $=34.4$ and 34.8, respectively). Model parameters for relative fecundity $v s$. TL were $a_{R F}=3.40 \mathrm{e}-07 \pm 2.29 \mathrm{e}-06$ and $b_{R F}=5.07 \pm 1.85$ for the power function, and $c_{R F}=0.16 \pm 0.31$ and $d_{R F}=0.14 \pm 0.05$ for the exponential function (Fig. 7b).
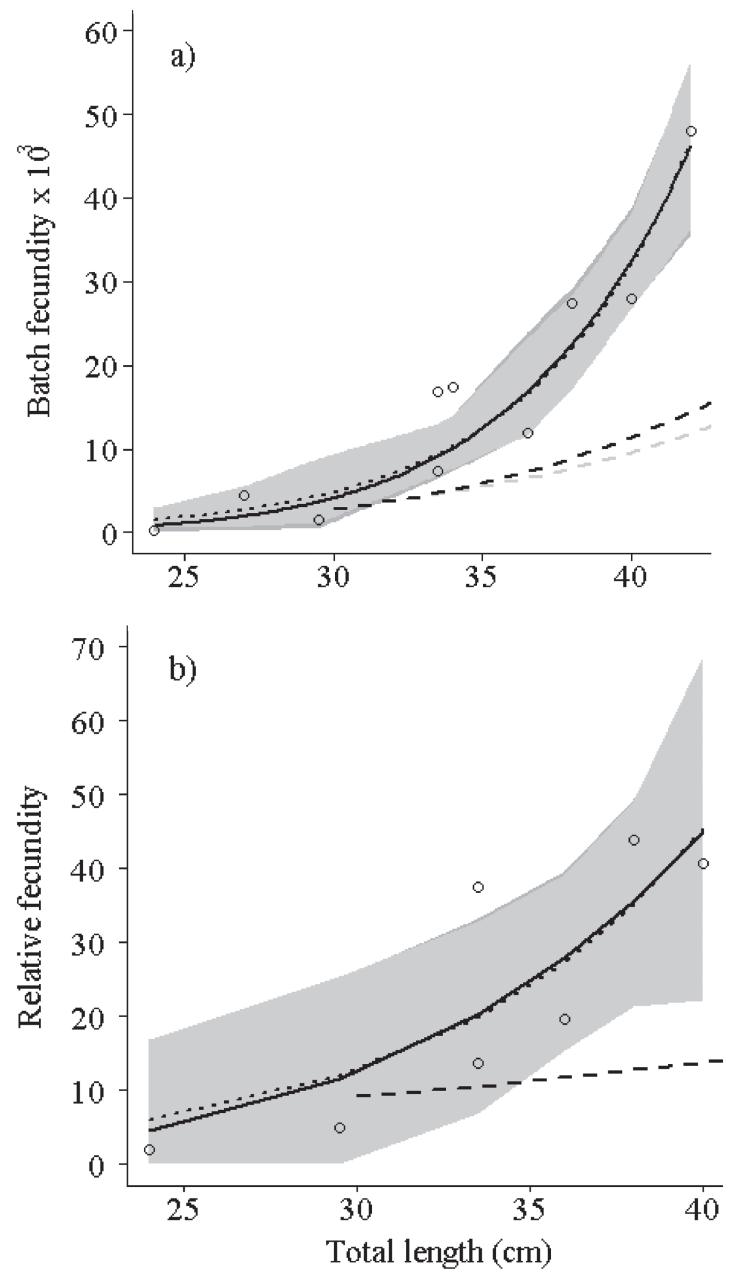

Fig. 7. Power (black lines) and exponential (dotted lines) relationships between (a) batch fecundity and total length, and (b) relative fecundity and total length in Pinguipes brasilianus. Shaded areas (grey and light grey, respectively) represent $95 \%$ confidence regions. Raw data are showed as open circles. Dashed lines show the same functions for $P$. chilensis, based on the function parameters reported by González Kother (2001).

\section{Discussion}

Some features of the reproductive biology of fishes, including the duration of the spawning season, the dynamics of oocyte maturation, and the type of fecundity and its extent, shape the population dynamics of a species by affecting the availability of early stages. Here we present the first study dealing with the reproductive biology of P. brasilianus, one of the two pinguipedid species that inhabits the coastal waters off Argentina. Although samples were not available for a few autumn months (i.e., May and June), and juveniles (i.e. fish $<15 \mathrm{~cm} \mathrm{TL}$ ) were not selected by the gears used to catch fish, apart from the fact that fish $<10 \mathrm{~cm}$ TL seem to be spatially segregated from the adults, our data covered most of the annual cycle and allowed us to infer about the general pattern. As fish came from a restricted coastal area $\left(41^{\circ} \mathrm{S}-\right.$ $43^{\circ} \mathrm{S}$ ), we assumed that they were no significant differences in the reproductive parameters of the populations sampled and hence data for all fish were pooled.

Pinguipes brasilianus shares the same general reproductive features of other pinguipedid fishes from the Southern tip of South America: P. chilensis and $P$. semifasciata: it is a dioicus species with external fecundity that releases several batches of oocytes throughout an extended spawning season (Macchi et al., 1995; González, 1998; González \& Oyarzún, 2002). This latter feature, together with the coexistence of oocytes from all developmental stages in the ovaries indicate that $P$. brasilianus is a multiple spawner. Besides, the occurrence of hydrated oocytes and POFs in most of the gravid females sampled pointed to a high spawning frequency in this species. The reproductive season for the Brazilian sandperch in Northern Patagonian waters peaks approximately between October and February, but some females were sampled in the spawning capable stage during previous months (i.e., August to October). As it occurs in other pinguipedids, male GSI values were low (monthly means ranged between $0.11 \%$ and $0.75 \%$ ). The estimated length at $50 \%$ maturity $( \pm \mathrm{SD})$ for females was $15.22 \pm 0.43 \mathrm{~cm}$ TL and the relative fecundity ranged between 2 and 44 oocytes $/ \mathrm{g}$ for fish between 24.0 and $40.0 \mathrm{~cm}$ TL.

The low batch fecundity and mean male GSI in $P$. brasilianus are consistent with a mating system involving a close proximity between the sexes at the time of spawning, sexual courtship or spawning in pairs and/or within reef crevices, as it is hypothesized to occur in P. semifasciata (Macchi et al., 1995; González, 2006; Venerus et al., 2008). In fishes with seasonal reproductive cycles, the relative investment of males in spermatogenesis, measured by the GSI, correlates with both the intensity of sperm competition (Stockley et al., 1997; Taborsky, 1998) and the type of spawning behaviour (Suquet et al., 1994). The occurrence of high male GSI values (i.e., maximum GSI $\geq$ $5 \%$ ) is common in species with communal spawning, where a strong sperm competition may occur (e.g.: serranids, Erisman \& Allen, 2006). Conversely, low male GSI values are associated with spawning generally in pairs (Warner, 
1997), where sperm competition may be reduced or absent (e.g., maximum GSI $<2 \%$ for some serranids belonging to the genera Cephalopholis Bloch \& Schneider 1801, Erisman et al., 2007). Most general, pinguipedid fishes have low male GSI values associated with the occurrence of haremic mating systems and/or territorial behaviours, for example, maximum GSI $=\sim 0.8 \%$ in Parapercis colias (Forster 1801) (extracted from fig. 1 in Pankhurst \& Conroy, 1987), and ranged between $0.09 \%$ and $0.31 \%$ in Parapercis cylindrica (Bloch 1792) (Walker \& McCormick, 2004), and between $0.02 \%$ and $0.14 \%$ in P. semifasciata (González, 1998). Mean male GSI values in $P$. brasilianus, reaching a maximum of $0.75 \%$, were in the same order of magnitude of those from other pinguipedids, and all of them were lower than the reported for $P$. chilensis, suggesting that some differences in the reproductive behavior among these species may occur.

Female length at $50 \%$ maturity also differed considerably between $P$. brasilianus and $P$. chilensis: while we estimated a $\mathrm{L}_{50}$ of about $15 \mathrm{~cm}$ for female P. brasilianus, González Kother (2001) reported $30 \mathrm{~cm}$ for $P$. chilensis. Nonetheless, the smallest female caught in her study was $28 \mathrm{~cm}$ TL (González Kother, 2001). Such a great difference in $\mathrm{L}_{50}$ between both species was most probably due to the lack of small fish in samples from Chile, which could have led to an overestimation of that parameter given that the greatest percentage increase in mean GSI between consecutive size groups (e.g., Finucane \& Collins, 1984) was the criterion used to determining size at maturity in $P$. chilensis (González Kother, 2001).

Relative fecundity in P. brasilianus was low compared with other South Atlantic species, like hakes (e.g., Merluccius hubbsi Marini, 1933: 85-1040 oocytes/g, for fish between 29 and $95 \mathrm{~cm}$ TL, Macchi et al., 2013) and sciaenids (mostly about 150-200 oocytes/g, Militelli et al., 2013). As a general rule, fecundity in fishes decreases with increasing egg size and increasing parental care (Helfman et al., 2009). In sciaenids inhabiting the Buenos Aires Coastal Zone off Argentina, Militelli et al. (2013) found support for this idea since Pogonias cromis (Linnaeus, 1766), the only species that had a smaller mean relative fecundity ranging between 75 and 98 oocytes/g, had also larger oocytes (1100-1400 $\mu \mathrm{m}$ in diameter) compared with the six remaining species studied, whose ooocyte diameters ranged between 750 and $900 \mu \mathrm{m}$. However, this inverse relationship between egg size and fecundity was not verified in the genera Pinguipes: $P$. brasilianus had higher batch and relative fecundity (Figs. 7a-b) and larger oocytes than $P$. chilensis (between 700 and $1100 \mu \mathrm{m}$ in P. brasilianus vs. $<500 \mu \mathrm{m}$ in P. chilensis, González Kother, 2001). Nonetheless, P. brasilianus showed a strong nonlinear positive relationship between relative fecundity and TL, which suggests possible maternal effects. However, this conclusion is based on limited data; hence this possibility should be further investigated. Regarding parental care, despite hundreds of hours of underwater observations on $P$. brasilianus were made by some of the authors (LAV and AJI) throughout the year (Irigoyen et al., 2013), no evidence supporting the occurrence of these mechanisms was gathered. Further, despite territorial behaviour is often observed, we never recorded any behavioral displays associated with reproduction, at least during daylight.

The reproductive seasonality in temperate fishes is mainly related to water temperature, photoperiod and food availability (McKaye, 1984; Payne, 1986). In subtropical environments, however, photoperiod seems to be a more important variable controlling the reproductive cycles (e.g., Giora \& Bernhardt Fialho, 2009; Oliveira et al., 2010). Here we found that, although photoperiod and SST were both related to variations in GSI, the photoperiod was a better predictor for GSI than SST. Regarding gonadal maturation, more than $85 \%$ of female $P$. brasilianus were found in the spawning capable stage between November and February, when daytime exceeded 13.5 hours and SST, $14.5^{\circ} \mathrm{C}$. However, about half of the females sampled during August and September were found in the spawning capable stage, as well as a third of the females sampled in October, with lower daytime duration and SST, while a significant proportion of spawning capable males were sampled throughout the year (Fig. S1, available as Supplementary Material). A similar pattern was also reported by González \& Oyarzún (2002) for P. chilensis.

The main difference between the spawning seasons between these species is that the reproductive peak for $P$. brasilianus extended between late spring and summer, while $P$. chilensis spawned mainly in summer and autumn. In Argentine waters, the spawning season of $P$. brasilianus overlapped partially with those from other rocky-reef fishes from Northern Patagonia, like $P$. semifasciata, whose spawning activity peaks between October and December (Elias \& Burgos, 1988; Macchi et al., 1995; González, 1998) and A. patachonicus, which spawns from September through December (Ciechomski \& Cassia, 1976; Dell'Arciprete et al., 1987). This is coincident with the seasonal formation of tidal fronts on the Argentinean shelf (e.g., North Patagonian frontal system, see Sabatini \& Martos, 2002 and citations therein; and San José gulf tidal front, see Amoroso \& Gagliardini, 2010) which enhances productivity and retention mechanisms which ensure diverse trophic opportunities for fish larvae and early juveniles (Sabatini \& Martos, 2002).

Our results provide a good starting point for further investigation about the ecology and reproductive behavior of $P$. brasilianus, which will help to fill a literature gap about these topics for pinguipedid species other than those belonging to the genera Parapercis.

\section{Acknowledgements}

Authors want to thank María Paula Sgarlatta, David Galván, Mariano Cuestas, María Vusica, Mariangeles López and Nelson Bovcon for their help to collect fish samples. Silvina Van der Molen, Nicolás Martinez and Cecilia Villanueva Gomila collaborated with laboratory 
work. Norma Luján helped with histology. Marta Estrada and Hugo Brachetta helped with the preparation of the histological sections. Gabriela Williams provided SST data. Paola González Kother kindly sent us her unpublished MSc Thesis about the reproductive biology of $P$. chilensis. Nora Glembocki and the editor helped with the English language and two anonymous reviewers made useful comments on an earlier version of the article. This study was funded by a grant from Agencia Nacional de Promoción Científica y Tecnológica (ANPCyT PICT 2010-2461) (granted to LAV). Field work was partially conducted within a UNESCO World Natural Heritage Site and authorized by the "Subsecretaría de Conservación y Areas Protegidas de Chubut".

\section{References}

Amoroso, R. O. \& D. A. Gagliardini. 2010. Inferring complex hydrographic processes using remote-sensed images: turbulent fluxes in the Patagonian gulfs and implications for scallop metapopulation dynamics. Journal of Coastal Research, 26: 320-332.

Beer, N. A., S. R. Wing \& G. Carbines. 2013. First estimates of batch fecundity for Parapercis colias, a commercially important temperate reef fish. New Zealand Journal of Marine and Freshwater Research, 47: 587-594.

Brown-Peterson, N. J., D. M. Wyanski, F. Saborido-Rey, B. J. Macewicz \& S. K. Lowerre-Barbieri. 2011. A Standardized terminology for describing reproductive development in fishes. Marine and Coastal Fisheries: Dynamics, Management, and Ecosystem Science, 3: 52-70.

Burnham, K. P. \& D. R. Anderson. 2004. Multimodel inference: understanding AIC and BIC in model selection. Sociological Methods \& Research, 33: 261-304.

Cailliet, G. M., M. S. Love \& A. W. Ebeling. 1986. Fishes: a field and laboratory manual on their structure, identification, and natural history. Belmont, California, wadworth Publishing, 194p.

Carbines, G. 2004. Age, growth, movement and reproductive biology of blue cod (Parapercis colias - Pinguipedidae): implications for fisheries management in the South Island of New Zealand. Unpublished Ph.D. Dissertation, University of Otago, Dunedin, New Zealand, 224p.

Ciechomski, J. D. \& M. C. Cassia. 1976. Características de la reproducción y fecundidad del mero, Acanthistius brasilianus, en el Mar Argentino (Pisces Serranidae). Physis, 35: 27-36.

Clopper, C. J. \& E. S. Pearson. 1934. The use of confidence or fiducial limits illustrated in the case of the binomial. Biometrika, 26: 404-413.

Dell'Arciprete, P., H. E. Christiansen \& J. M. Díaz de Astarloa. 1987. Observaciones sobre el ciclo reproductivo del mero, Acanthistius brasilianus (Serranidae, Pisces). Revista de Investigación y Desarrollo Pesquero, 7: 67-84.

Elias, I. \& G. Burgos. 1988. Edad y crecimiento del "salmón de mar", Pseudopercis semifasciata (Cuvier, 1829) (Osteichthyes, Pinguipedidae) en aguas norpatagónicas argentinas. Investigación Pesquera, 52: 533-548.

Erisman, B. E. \& L. G. Allen. 2006. Reproductive behaviour of a temperate serranid fish, Paralabrax clathratus (Girard), from Santa Catalina Island, California, U.S.A. Journal of Fish Biology, 68: 157-184.
Erisman, B. E., M. L. Buckhorn \& P. A. Hastings. 2007. Spawning patterns in the leopard grouper, Mycteroperca rosacea, in comparison with other aggregating groupers. Marine Biology, 151: 1849-1861.

Finucane, J. H. \& L. A. Collins. 1984. Reproductive biology of cero, Scomberomorus regalis, from the coastal waters of South Florida. Northeast Gulf Science, 7: 101-107.

Galván, D. E. 2008. Ensambles de peces en los arrecifes norpatagónicos: diversidad, abundancia y relaciones tróficas y con el hábitat. Unpublished Doctoral Dissertation, Universidad Nacional Del Comahue, Bariloche, Río Negro, Argentina, 129p.

Galván, D. E., L. A. Venerus \& A. J. Irigoyen. 2009a. The reeffish fauna of the Northern Patagonian gulfs, Argentina, Southwestern Atlantic. The Open Fish Science Journal, 2: 90-98.

Galván, D. E., F. Botto, A. M. Parma, L. Bandieri, N. Mohamed \& O. O. Iribarne. 2009b. Food partitioning and spatial subsidy in shelter-limited fishes inhabiting patchy reefs of Patagonia. Journal of Fish Biology, 75: 2585-2605.

García del Moral Martín, R. 1993. Laboratorio de anatomía patológica. Madrid, Mc Graw-Hill, Interamericana de España, 657p.

Giora, J. \& C. Bernhardt Fialho. 2009. Reproductive biology of weakly electric fish Eigenmannia trilineata López and Castello, 1966 (Teleostei, Sternopygidae). Brazilian Archives of Biology and Technology, 52: 617-628.

González, R. A. C. 1998. Biología y explotación pesquera del salmón de mar Pseudopercis semifasciata (Cuvier, 1829) (Pinguipedidae) en el Golfo San Matías, Patagonia, Argentina. Unpublished PhD. Doctoral Dissertation, Universidad Nacional del Sur, Bahía Blanca, Buenos Aires, Argentina, 135p.

González, R. A. C. 2006. Age and growth of the Argentine sandperch Pseudopercis semifasciata (Cuvier, 1829) Berg, 1899 in the San Matías Gulf (Patagonia, Argentina). Fisheries Research, 79: 120-128.

González, P. \& C. Oyarzún. 2002. Variabilidad de índices biologicos en Pinguipes chilensis Valenciennes 1833 (Perciformes, Pinguipedidae): ¿Estan realmente correlacionados? Gayana (Concepción), 66: 249-253.

González Kother, P. A. 2001. Biología reproductiva y conducta trófica de Pinguipes chilensis Valenciennes, 1833 (Perciformes: Pingipedidae). Unpublished MSc. Dissertation, Universidad de Concepción, Concepción, Chile, 158p.

Grothendieck, G. 2007. nls2: Non-linear regression with brute force. R package version 0.1-2. Available from: http:// CRAN.R-project.org/package=nls2. (30 Apr 2015).

Helfman, G. S., B. B. Collette, D. E. Facey \& B. W. Bowen. 2009. The diversity of fishes: In Biology, evolution, and ecology. $2^{\text {nd }}$ ed. Chichester, UK, Hoboken, N.J., Wiley-Blackwell, 720p.

Herrera, M. E. \& M. B. Cousseau. 1996. Comparación del esqueleto óseo de dos especies de peces de la familia Pinguipedidae. Naturalia Patagónica (Ciencias Biológicas), 4: 95-110.

Holm, S. 1979. A simple sequentially rejective multiple test procedure. Scandinavian. Journal of Statistics, 6: 65-70.

Hunter, J. R., N. C. H. Lo \& R. J. H. Leong. 1985. Batch fecundity in multiple spawning fishes. Pp. 67-77. In: Lasker, R. (Ed.). An egg production method for estimating spawning biomass of pelagic fish: application to the Northern Anchovy, Engraulis mordax. Springfield, J.A, NOAA. (NOAA Technical Report NMFS, 36). 
International Council for the Exploration of the sea (ICES). 2008. Report of the Workshop on Maturity Ogive Estimation for Stock Assessment (WKMOG), 3-6 June 2008, Lisbon, Portugal. Copenhagen, ICES, 68p. (ICES CM2008/ACOM:33. ICES WKMOG Report 2008) Available from: http://www.ices. $\mathrm{dk} /$ sites/pub/Publication\%20Reports/Expert\%20Group\%20 Report/acom/2008/WKMOG/WKMOG08.pdf (15 July 2015).

Irigoyen, A. J., D. E. Galván, L. A. Venerus \& A. M. Parma. 2013. Variability in abundance of temperate reef fishes estimated by visual census. PLoS ONE, 8: e61072 (12p.).

Macchi, G. J., I. Elias \& G. E. Burgos. 1995. Histological observations on the reproductive cycle of the Argentinian sandperch, Pseudopercis semifasciata (Osteichthyes, Pinguipedidae). Scientia Marina, 59: 119-127.

Macchi, G. J., E. Leonarduzzi, M. V. Díaz, M. Renzi \& K. Rodrigues. 2013. Maternal effects on fecundity and egg quality of the Patagonian stock of Argentine hake (Merluccius hubbsi). Fishery Bulletin, 111: 325-336.

McCullagh, P. \& J. A. Nelder. 1989. Generalized linear models, $2^{\text {nd }}$ ed. Boca Raton, Chapman \& Hall/CRC, 511p. (Monographs on Statistics and Applied Probability 37).

McKaye, K. R. 1984. Behavioural aspects of ciclid reproductive strategies: patterns of territoriality and brood defence in Central American substratum spawners and African mouth brooders. Pp. 245-273. In: Potts, G. W. \& R. J. Wooton (Eds.). Fish reproduction: strategies and tactics. London, Academic Press.

Militelli, M. I., G. J. Macchi \& K. A. Rodrigues. 2013. Comparative reproductive biology of Sciaenidae family species in the Río de la Plata and Buenos Aires Coastal Zone, Argentina. Journal of the Marine Biological Association of the United Kingdom, 93: 413-423.

Murua, H. \& F. Saborido-Rey. 2003. Female reproductive strategies of marine fish species of the North Atlantic. Journal of Northwest Atlantic Fishery Science, 33: 23-31.

Nelson, J. S. 2006. Fishes of the world. $4^{\text {th }}$ ed. Hoboken, N.J., J. Wiley \& Sons, 601p.

Oliveira, C. L. C., C. B. Fialho \& L. R. Malabarba. 2010. Reproductive period, fecundity and histology of gonads of two cheirodontines (Ostariophysi: Characidae) with different reproductive strategies - insemination and external fertilization. Neotropical Ichthyology, 8: 351-360.

Orsi Relini, L. 2002. Occurrence of the South American fish Pinguipes brasilianus (Pinguipedidae) in the Mediterranean. Cybium, 26: 147-149.

Otero, H., S. I. Bezzi, M. Renzi \& G. Verazay. 1982. Atlas de los recursos pesqueros demersales del Mar Argentino. Mar del Plata, INIDEP, 248p. (Contribución Instituto Nacional de Investigación y Desarrollo Pesquero, (INIDEP), n. 423).

Pankhurst, N. W. \& A. M. Conroy. 1987. Seasonal changes in reproductive condition and plasma levels of sex steroids in the blue cod, Parapercis colias (Bloch and Schneider) (Mugiloididae). Fish Physiology and Biochemistry, 4: 15-26.

Payne, A. I. 1986. The ecology of tropical lakes and rivers. Chichester, New York, J. Wiley \& Sons, 301p.

Pinheiro, J., D. Bates, S. DebRoy, D. Sarkar \& R Development Core Team. 2014. nlme: Linear and nonlinear mixed effects models. R package version 3.1-117. Available from: http://CRAN.Rproject.org/package=nlme. (10 Apr 2015).

Quade, D. 1979. Using weighted rankings in the analysis of complete blocks with additive block effects. Journal of the American Statistical Association, 74: 680-683.
R Development Core Team. 2014. R: A language and environment for statistical computing. R Foundation for Statistical Computing, Vienna, Austria. Available from: http://www.Rproject.org/. (30 Apr 2015).

Rosa, I. L. \& R. S. Rosa. 1997. Systematic revision of the South American species of Pinguipedidae (Teleostei, Trachinoidei). Revista Brasileira de Zoologia, 14: 845-865.

Sabatini, M. \& P. Martos. 2002. Mesozooplankton features in a frontal area off Northern Patagonia (Argentina) during spring 1995 and 1998. Scientia Marina, 66: 215-232.

Sanabra, F. 2002. Buceando recuerdos: matices de la historia del buceo en la Argentina. Puerto Madryn, Ocean Ediciones Submarinas, 148p.

Stockley, P., M. J. G. Gage, G. A. Parker \& A. P. Moller. 1997. Sperm competition in fishes: the evolution of testis size and ejaculate characteristics. The American Naturalist, 149: 933-954.

Stroud, G. J. 1982. The taxonomy and biology of fishes of the genus Parapercis (Teleostei: Mugiloididae) in Great Barrier Reef waters. Unpublished Ph.D. Dissertation, James Cook University of North Queensland, Townsville, Australia, 555p.

Suquet, M., R. Billard, J. Cosson, G. Dorange, L. Chauvaud, C. Mugnier \& C. Fauvel. 1994. Sperm features in turbot (Scophthalmus maximus): a comparison with other freshwater and marine fish species. Aquatic Living Resources, 7: 283-294.

Taborsky, M. 1998. Sperm competition in fish: "bourgeois" males and parasitic spawning. Trends in Ecology and Evolution (TREE), 13: 222-227.

Timi, J. T., A. L. Lanfranchi \& J. L. Luque. 2010. Similarity in parasite communities of the teleost fish Pinguipes brasilianus in the southwestern Atlantic: infracommunities as a tool to detect geographical patterns. International Journal for Parasitology, 40: 243-254.

Venerus, L. A. 2006. Dinámica espacial del salmón de mar Pseudopercis semifasciata (Cuvier, 1829) (Pinguipedidae) - Implicancias para el uso sustentable de los sistemas de arrecifes rocosos. Unpublished Doctoral Dissertation, Universidad de Buenos Aires, Ciudad Autónoma de Buenos Aires, Argentina, 182p.

Venerus, L. A., A. M. Parma \& D. E. Galván. 2008. Annual occupation pattern of temperate rocky reefs by the Argentine sandperch Pseudopercis semifasciata in San José Gulf Marine Park, Argentina. Fisheries Management and Ecology, 15: 217-229.

Walker, S. P. W. \& M. I. McCormick. 2004. Otolith-check formation and accelerated growth associated with sex change in an annual protogynous tropical fish. Marine Ecology Progress Series, 266: 201-212.

Warner, R. R. 1997. Sperm allocation in coral reef fishes: strategies for coping with demands on sperm production. BioScience, 47 : 561-564.

West, G. 1990. Methods of assessing ovarian development in fishes: a review. Australian Journal of Marine \& Freshwater Research, 41: 199-222.

Zuur, A. F., E. N. Ieno, N. J. Walker, A. A. Saveliev \& G. M. Smith. 2009. Mixed effects models and extensions in ecology with R. New York, Springer, 574p.

Submitted May 04, 2015

Accepted September 20, 2015 by Franco Teixeira de Mello Published December 15, 2015 